\title{
Keeping Cinema's Memory Alive in Hong Kong: An Interview with Bede Cheng, Managing Director at L'Immagine Ritrovata Asia
}

Andrea Gelardi

https://doi.org/10.15664/fcj.v0i17.2066

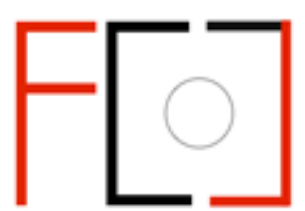

Frames Cinema Journal

ISSN 2053-8812

Issue 17 (Jun 2020)

(c) $\underset{\mathrm{EY}}{\mathrm{i}}$

http://www.framescinemajournal.com 


\section{Keeping Cinema's Memory Alive in Hong Kong: An Interview with Bede Cheng, Managing Director at L'Immagine Ritrovata Asia \\ Andrea Gelardi}

In March 2019, Professor Dina Iordanova asked me to contribute to a dossier focusing on film archives in Asia. I was particularly thrilled by this project, which aims to highlight the history, work, and latest developments of archival organisations and film heritage institutions operating in Southeast Asia. Following the publication of the UNESCO Recommendation for the Safeguarding and Preservation of Moving Images (1980), this region has witnessed a boom in attention towards the safeguarding of cinema's memory. Indeed, under the aegis of UNESCO and FIAF, several new film heritage institutions were established in the Asian region between the late 1980s and the 2000s, such as the Thai Film Archive (1984), the Hong Kong Film Archive (1993), the ABS-CBN Film Archives in the Philippines (1994), and the Singapore-based Asian Film Archive (2005), each mandated with the specific aim to protect its nation's film heritage. ${ }^{1}$

With "classic films" establishing a thriving market in the long-tailed catalogues of VOD platforms and gaining visibility through the international film festival circuit, the preservation and restoration of Asian film heritage(s) has become an appealing target for media giants and film heritage institutions throughout the last decade. By fostering various forms of trans-regional and transcontinental co-operation, which is often necessary to retrieve the "original" copies - when they actually exist - of a film, the archival movement in this region bears further evidence of the essentially transnational history of cinema and film culture.

To investigate these and many other compelling issues, we have interviewed Bede Cheng who currently serves as Managing Director at the film restoration laboratory L'Immagine Ritrovata Asia. The interview provides an overview of Cheng's personal voyage through the archival world, that includes valuable insights into an extremely rich field which is rapidly transforming under the challenges of competing interests (the national, the commercial and the cultural). 


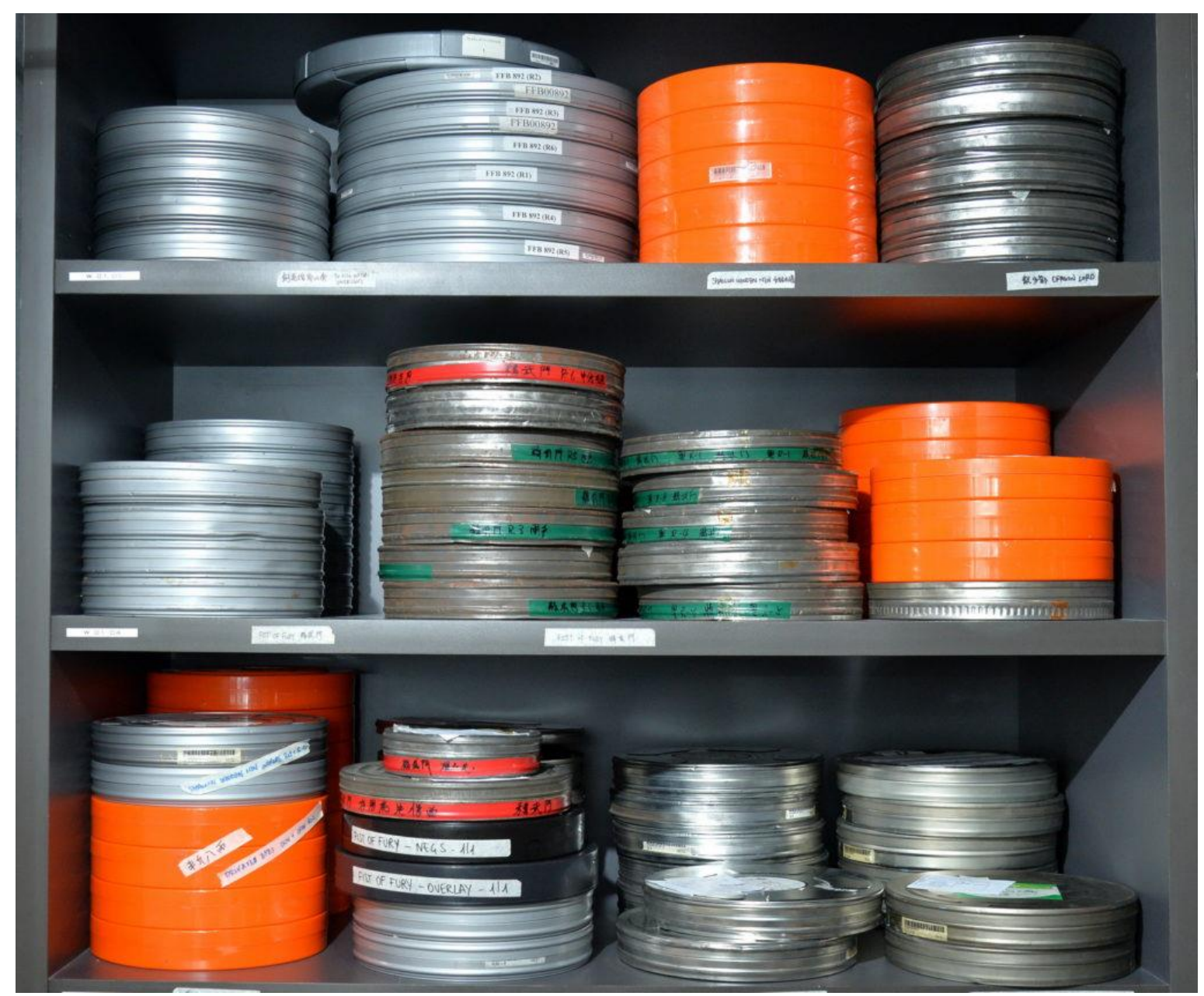

Figure 1: L'Immagine Ritrovata Asia: film cans

Andrea Gelardi (AG): Can you tell me about your educational background, and professional experience? How has your involvement in film archiving and curatorship emerged and evolved?

Bede Cheng (BC): I started off working for a Chinese language TV company, back in the day, in the 1990s, when I was living and attending college in San Francisco (California, USA). The company I worked for was a small, ethnic TV station catering to the Chinese community living in the US - if you have an idea of this kind of TV networks.

While I was working there, I continued cultivating my interest in films as well. So, I decided to enrol at a film school and, like many aspiring filmmakers, I thought I would make my film straight after. Looking back, this sounds kind of naïve of me. However, in those years I used to listen to a Chinese language radio programme, and once in a while it featured Lambert Yam, the owner of the San Francisco Chinatown's film theatre, promoting the films shown at his cinema. At that time Lambert was a film distributor of Hong Kong films, representing the sellers in Hong Kong and distributing the films through a network of film theatres based in the various US Chinatowns. Eventually I got to know him and this was my formal introduction to the world of film industry.

In those years I developed a special interest in arthouse films, and so I decided to go to the University College of Los Angeles. During my university years, I was hired for a part-time job in 
a film theatre in Los Angeles that had just opened. My duty was to sell tickets and candies, then go upstairs and start the movie with the projector. After that, I'd come back to sell more candies and popcorn. After a while, I moved back to San Francisco to work for the World Theatre, where a lot of Hong Kong films were shown for the first time in North America. After the films were shown they were just left in the theatre. Though the World Theatre closed in the early 2000s, it played a very important role for Hong Kong films. Most of the Hong Kong films were repatriated from there to the Hong Kong Film Archive. In some cases, these were titles that were unavailable even in Hong Kong. I have also had the chance to work on movie sets, doing different jobs, like being assistant director and script supervisor on some action movies that were being shot in North America, such as Rumble in the Bronx (Stanley Tong, Hong Kong, 1995) and Once Upon a Time in Cbina in America (Sammo Hung and Lau Kar-wing, Hong Kong / China, 1997). That is how I got to work in the film industry, but soon after I came to realise that I was more interested in nonmainstream cinemas and telling people about films.

When I moved back to Hong Kong, around 1997, I started working as assistant for the Hong Kong International Film Festival (HKIFF). On this occasion, I met Law Kai, a living encyclopaedia of Hong Kong cinema, and other programmers of the festival. In 2000, the Hong Kong Film Archive (HKFA) was founded, and since Law Kai was hired as Programmer-in-Chief, I got involved with the constitution of the local archive, where I worked until 2006. Since then, I continued working with the HKIFF until 2013, when I was hired as programmer to run an alternative festival: the Sundance Film Festival Hong Kong (SFFHK). The same year, Davide Pozzi from L'immagine Ritrovata in Bologna informed me that they were going to set up a restoration laboratory in Hong Kong to facilitate the restoration of films from the Asian region. In 2015, the L'Immagine Ritrovata Asia lab was established in Hong Kong, and I was appointed its director. I have worked there since then.

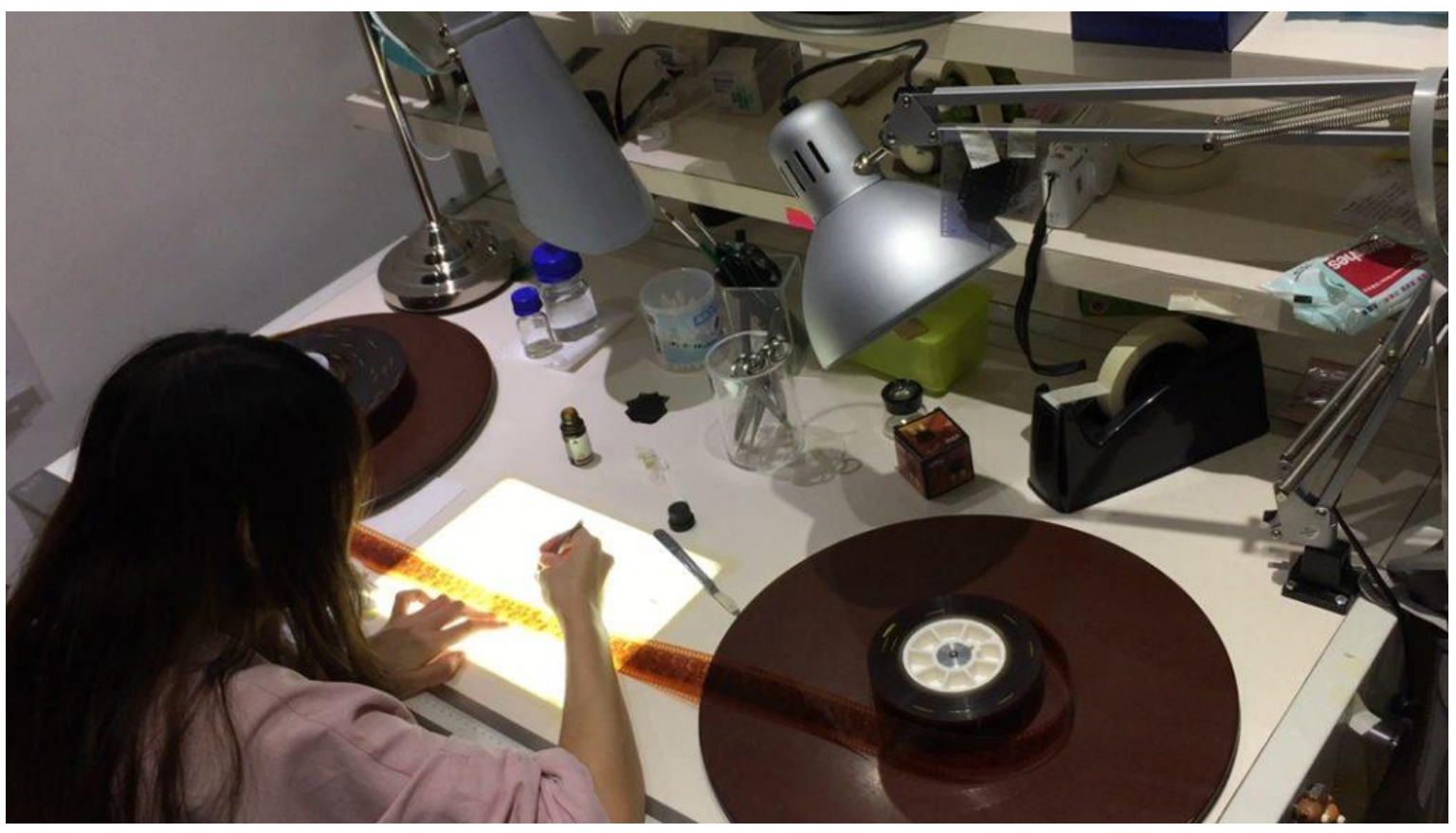

Figure 2: L'Immagine Ritrovata Asia: Lau Gladys repairing a film 
AG: Did you have first-hand experience of the FIAF's Summer Schools and, if this is the case, how seminal where they in your later career? The number of academic curricula and professional courses devoted to film restoration and conservation has slowly but significantly increased throughout the last twenty years. As an established professional in the field, what can you say about this fairly recent trend, and what do you deem as crucial in the education of a film archivist?

BC: Despite the terrible heat, my experience at the FIAF summer school in Bologna was very helpful for my current job at the L'Immagine Ritrovata Asia, particularly in terms of networking. The school was a chance to meet many people from different parts of the world, and working in the field was helpful for my future. I decided to attend the summer school for my personal interest and to learn something more about film restoration, even though my work as assistant for the HKIFF was not related at all with it. Today, I see lots of people with nothing to do with archival work, who are working in the film industry or in film distribution, that decide to apply for the FIAF summer schools on their own initiative.

In general, I believe that you need an all-round education to work in a film archive. You need to know about history, of course, because film archiving requires the knowledge of how films were made physically and distributed at a certain point in history. Personally, I think that the best way to know about cinema and its history is to see as many films as possible. Then, as film archivists, our mission is to attract new and young audience to the films of the past. Nowadays, my work is mostly dealing with people collecting old movies and often most of them ignore basic information such as the aspect ratio of a film or how it was made. In this sense, I think it would be good to have some background understanding of film archiving. For instance, in a film history course, it would be helpful to have a number of classes that give a walkthrough of film archiving so that students have a better idea of all the effort that it takes to keep a film alive - especially since many of the younger generation watch films on their iPhones or laptops. 


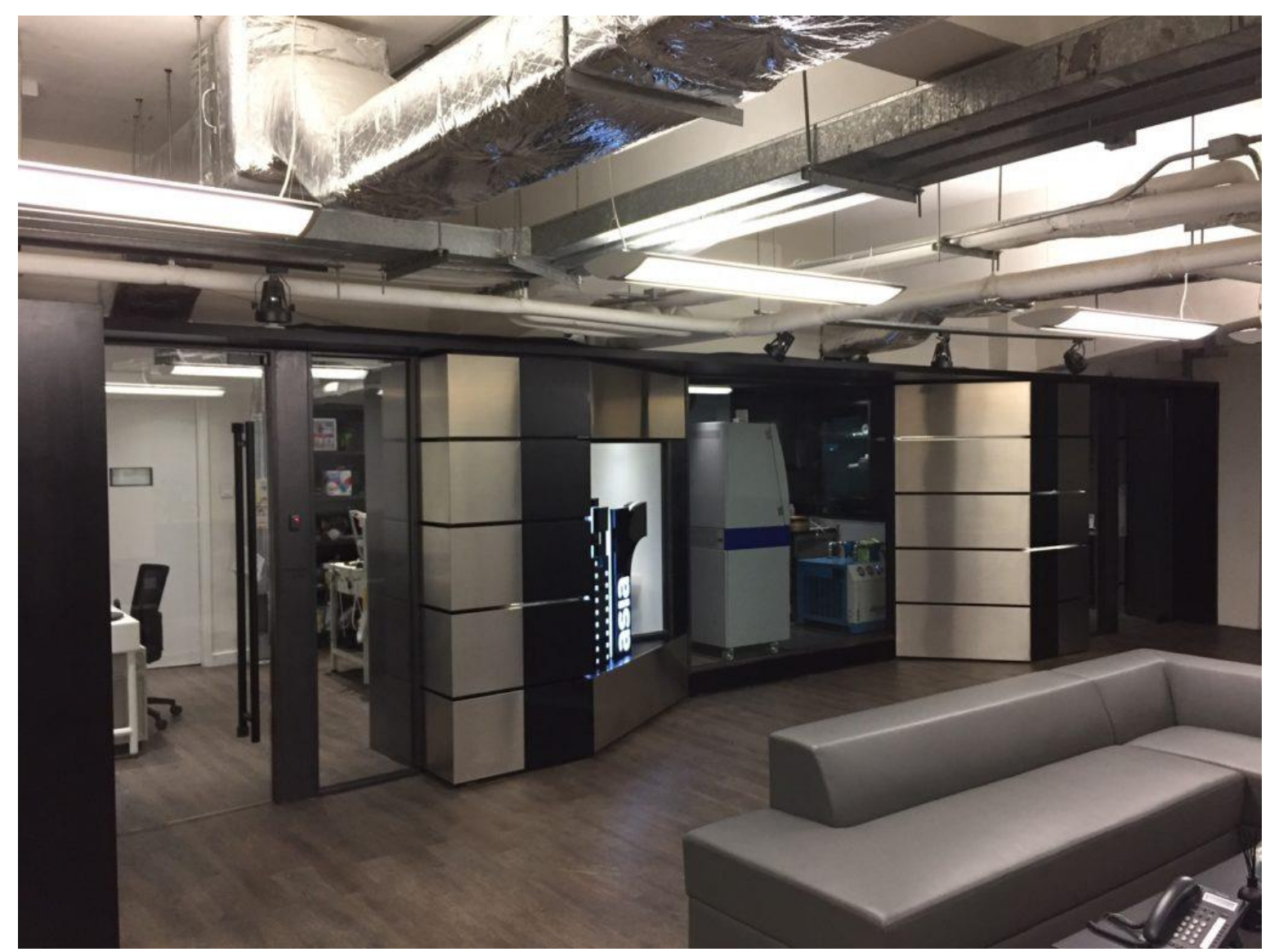

Figure 3: L'Immagine Ritrovata Asia: Entrance Hall

AG: What are the specific processes carried out at the L'Immagine Ritrovata Asia laboratory? Does the laboratory store celluloid films?

BC: Yes, here we do store films from our clients, and some people go crazy when they find out we have a film collection. We do have a film collection, because we always prefer to do the restoration from original negatives. We basically carry out one third of the whole restoration process which is the transfer from analogue to digital. We scan the films and turn them into digital files. Then we send them to Italy for further processing. So, that's what we do here, and of course we have several workstations as well. This means we can do some minor adjustment work here. Some of our clients had made comments about the fact that they could not be involved in the restoration work. Therefore, we decided to set up some new workstations here in case the clients would like to see the developments or indicate eventual corrections with the light colour, for example.

Specifically, we handle the film, clean it, and check its integrity, because sometimes the original negatives were prepared very hastily to make the release deadlines. One thing that we do here is that we take out the tape that was on the original negative because it was processed into the interpositive very quickly. This is because films from Hong Kong cinema are usually made in a very short time. We need to take the tape out because our scanner is very sensitive, and the tape would affect the scanning process. In the case of Hong Kong action movies, they were edited very heavily and we usually have films with an edit every three frames. It takes about a week to prepare a reel of let's say one thousand feet [three hundred metres]. Scanning then takes about eight to ten hours 
for $4 \mathrm{~K}$ resolution. A $2 \mathrm{~K}$ scan is much shorter. Once it is digitised, it is sent to Bologna. We do our best to keep the original negative in our shelter here until the whole restoration process is completed. When we are sure that the negative won't be necessary again it can be returned to the client.

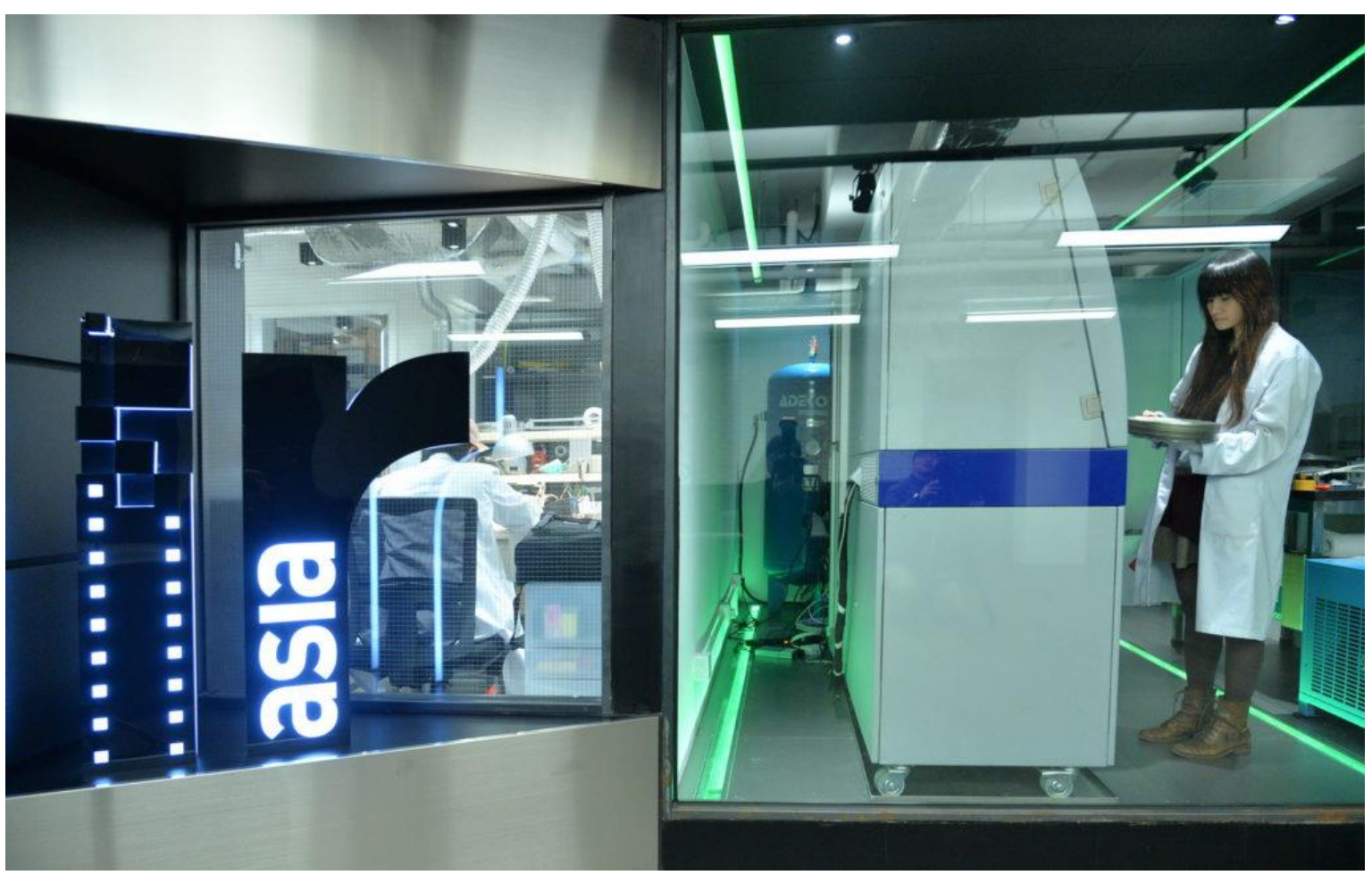

Figure 4: L'Immagine Ritrovata Asia: view of the lightbox and the digital scanner

AG: Can you describe the administrative arrangements and the relationship between the L'Immagine Ritrovata Asia and the Fondazione Cineteca di Bologna? In terms of decision making, how is the Hong Kong laboratory accountable, and can it propose restoration projects? In this regard, could you provide any example from your own experience?

BC: The Foundation Cineteca di Bologna is our big boss of course. The laboratory was set up through funds by the Italian government that promoted and contributed financially to overseas business. However, we do not have much to do with the Foundation, administration-wise. Our clients are from Hong Kong, Taiwan, Philippines, Singapore, Korea and Japan. They can send the films directly here to be scanned, and they don't need to send them all the way to Italy anymore. Davide Pozzi from L'Immagine Ritrovata in Bologna asked me to work here because of my connections in the film industry in Hong Kong and South East Asia, which I made while I was working at HKIFF. Yes, we can propose the restoration of films, of course, and I can also say that the Hong Kong Laboratory is very independent in a way. People in the industry know that I work here at the lab. I receive some proposals every now and then, and sometimes these end up being restoration projects. 


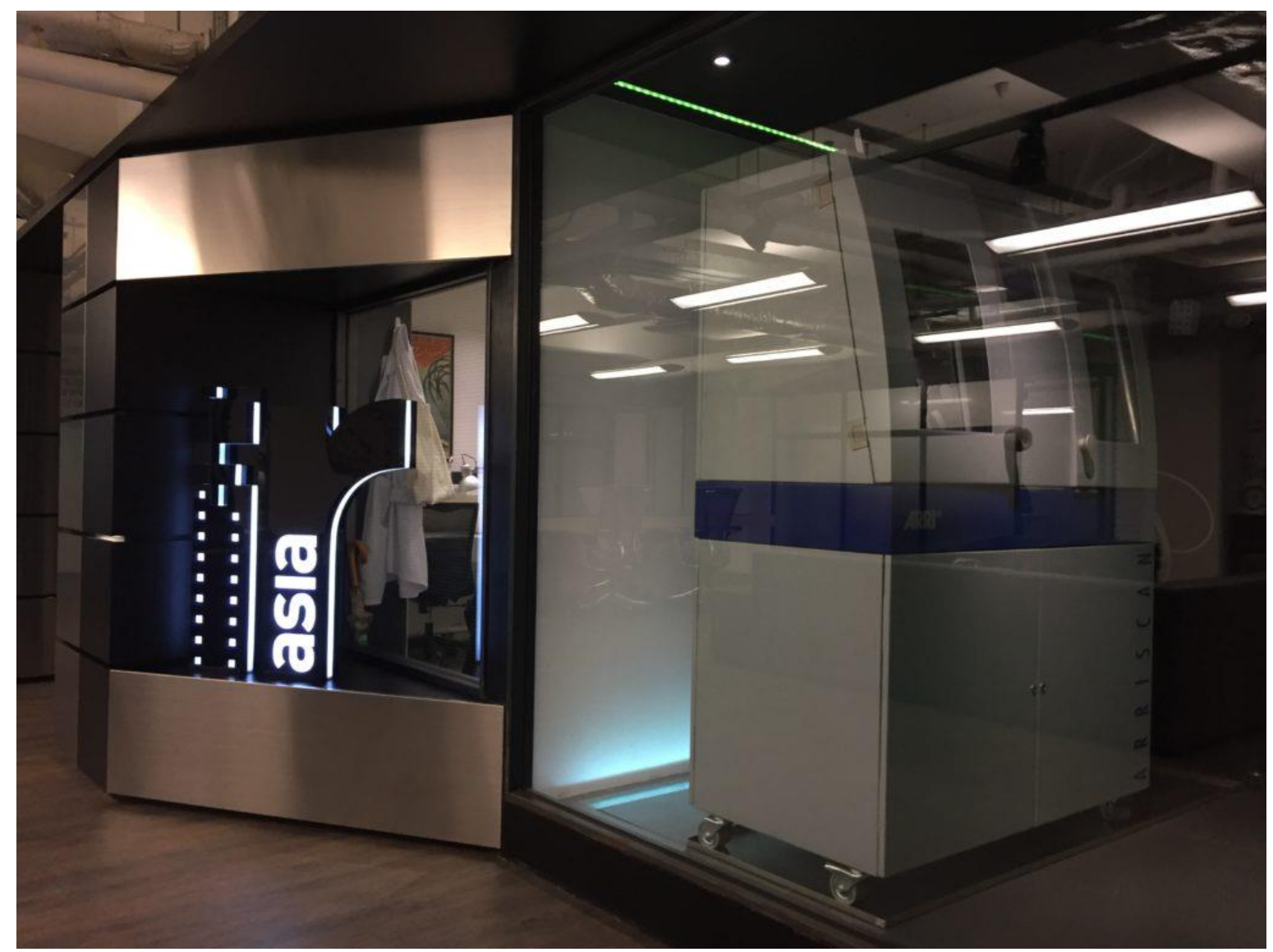

Figure 5: L'Immagine Ritrovata Asia: view of the digital scanner

AG: With environmental hazards and natural disasters in mind, how do you plan the safeguarding of your physical and digital assets?

BC: We are based in a very old building, and there is not much we can do to modify the place. If we wanted to stick to all the protocols it would be extremely expensive, and we do not have enough space to fit all of the instruments. We keep the place cool though and do have a fire cabinet where we keep the nitrates because they can combust. We also have an alarm system that monitors the internal temperature in case something goes wrong.

AG: Do you cooperate with other local cultural institutions, such as universities, schools, and museums?

BC: We don't have a long-term relationship with urban institutions at the moment, no. We sometimes have visits by Hong Kong University students, mostly from the Department of Film Studies, because lecturers want to show students what films actually look like. For the last two years, we have worked with Asian Film Awards Academy, which has some kind of internship to send people from Hong Kong to the L'Immagine Ritrovata in Bologna for about six weeks to learn about film restoration. I would jump on that if I could qualify. Actually, starting from 2020, the Hong Kong International Film Festival Society is going to collaborate with the Cineteca di Bologna to do a kind of miniature version of Il Cinema Ritrovato film festival here in Hong Kong. I think an organisation in Shanghai is planning something similar as well. 


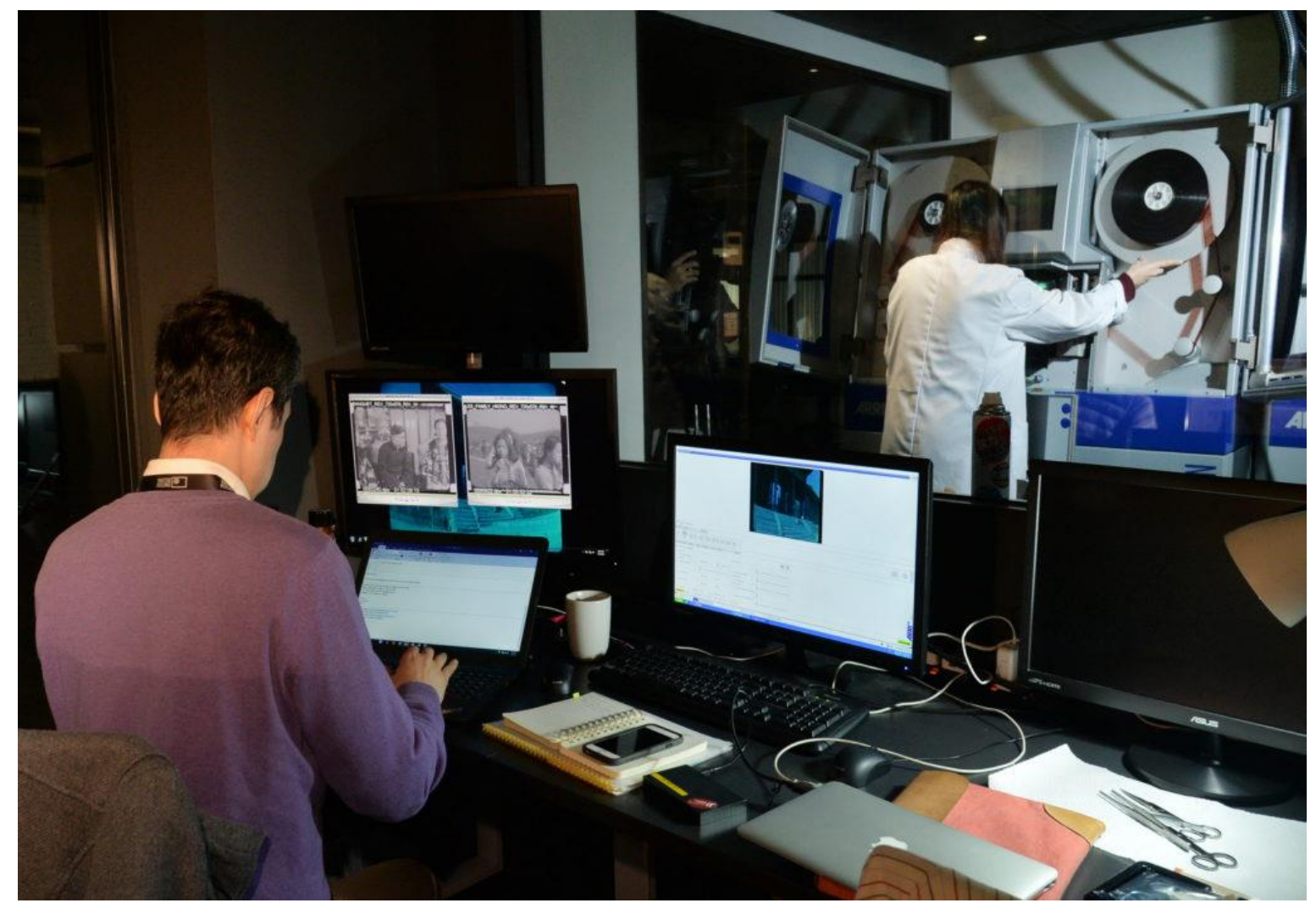

Figure 6: L'Immagine Ritrovata Asia: view of the quality control room

AG: The L'Immagine Ritrovata Asia works at the forefront of film restoration and conservation in Southeast Asia. How has the attention towards film preservation evolved in the Southeast Asian area? What are the main challenges film heritage institutions face in this region?

BC: Of course, our location has drawn more attention among people working in the film industry in this region. Film restoration was more a European and North American thing in the past. Now, I think that more people in Asia know the importance of this work and that film represents a form of national heritage. As someone who has lived in Hong Kong for most of his life, I think I know what Hong Kong films are worthy of being restored. For instance, a lot of film festivals around the world have people locally seeking what films should be shown. I see them all the time. They go around gathering information about what new films are being made, and then, maybe, the festival programmer flies over here to check out the films that the local consultant has spotted. I think in terms of film restoration, it can also be done in this way, with local consultants spotting what films are in need, and worthy, of being restored. However, it's not just a matter of heritage but of money as well.

Film preservation is becoming a profitable business, particularly with new streaming platforms needing large amounts of content to fill up all their categories. Look at Netflix, for instance. Netflix is showing a lot of Hong Kong films made in the 1980s and 1990s, but once you click on the film you realise that the quality is not good. I think the streaming service would be ready to pay for better quality or to fund restoration projects. Distributors know that in order to sell a film to a streaming service they need to have a $4 \mathrm{~K}$ version, because TVs and hardware are going to have a 
$4 \mathrm{~K}$ resolution. Therefore, distributors need to scan and restore films in $4 \mathrm{~K}$. The economy and profits are the driving forces, even in this case. Local film studios are approaching us to do the scanning and carry out other processes because they know there is a market for old movies, and it is a " $4 \mathrm{~K}$ market". For instance, we are currently working with the Criterion Collection right now to restore all of Wong Kar-Wai's films. We have completed about two thirds of the work and are also contributing to locating the originals.

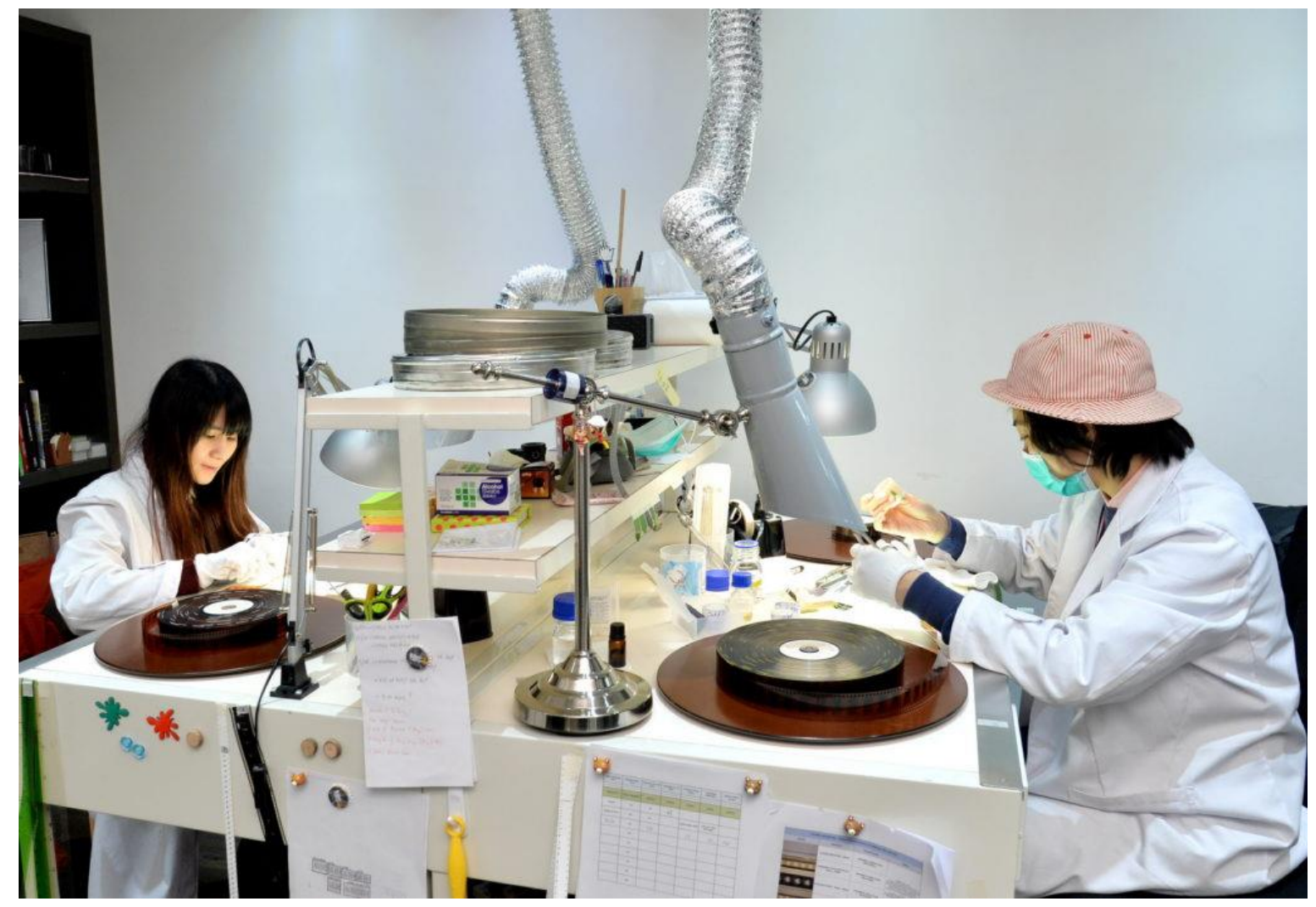

Figure 7: L'Immagine Ritrovata Asia: repair room

AG: For the restoration of Eric Khoo's Mee Pok Man (1995), L'Immagine Ritrovata and L'Immagine Ritrovata Asia have cooperated with the Asian Film Archive in Singapore to preserve a fundamental tile in the wider mosaic of Asian film history. Can you tell us more about this project?

BC: Finding the right material is one of the main challenges for us, since a lot of original materials cannot be retrieved. Films from the 1980s, in particular, are not very well kept and are all over the place. It is difficult to find the negatives, and of course there are also problems with temperature and humidity. For instance, the films we retrieve from the Philippines are usually in very bad condition.

Vinegar syndrome and celluloid films sticking together are the most common issues we come across. Once, one of my colleagues got sick by opening one of the films. Now I know what the mummy's curse is! Fungus, bacteria, and especially the mould, because it grows rapidly and has a complex organic structure. Films are made up of several layers of plastic, and the mould grows 
between the plastic layers. In these cases, there is nothing we can do but remove them digitally because you cannot tear the mould from the film.

Of course, the rights of films are kind of messy, because you do not know who owns them. Copyright issues are a major obstacle preventing films from getting restored. The Asian Film Archive (AFA) is one of our partners in the area. We started cooperating with AFA on the Mee Pok Man (Eric Khoo, 1995, Singapore) restoration project, and that was one of the first projects we scanned here at the lab. Though AFA is based in Singapore, it does not only restore Singaporean films. In fact, we are currently cooperating with them on a Sri Lankan film. We also cooperate with the ABS-CBN (Alto Broadcasting System-Chronicle Broadcasting Network) on the restoration of the cinema of Philippines. Actually, one of the good things about working here is that I get to know a lot of Asian cinemas that I have never heard about before. We did a lot of work on Philippine Cinema and it was a kind of discovery for me that this cinema in the 1970s was so good. Lino Brocka, Mike de León, Ishmael Bernal, and also commercial cinema is very well made.

AG: Do you cooperate with film heritage institutions based in the People's Republic of China, such as the China Film Archive in Beijing?

BC: We have restored a number of films that were previously scanned in mainland China. It was a joint project with the Shanghai International Film Festival (SIFF), because we had carried out some restoration projects for them. SIFF had funding to restore one Chinese language film, and that is how John Woo's A Better Tomorrow (Hong Kong, 1986) was restored. This year it was Hou Hsiao-Hsien's Flowers of Shanghai (Taiwan, 1998). However, we have not cooperated with any Chinese film archive to date. 


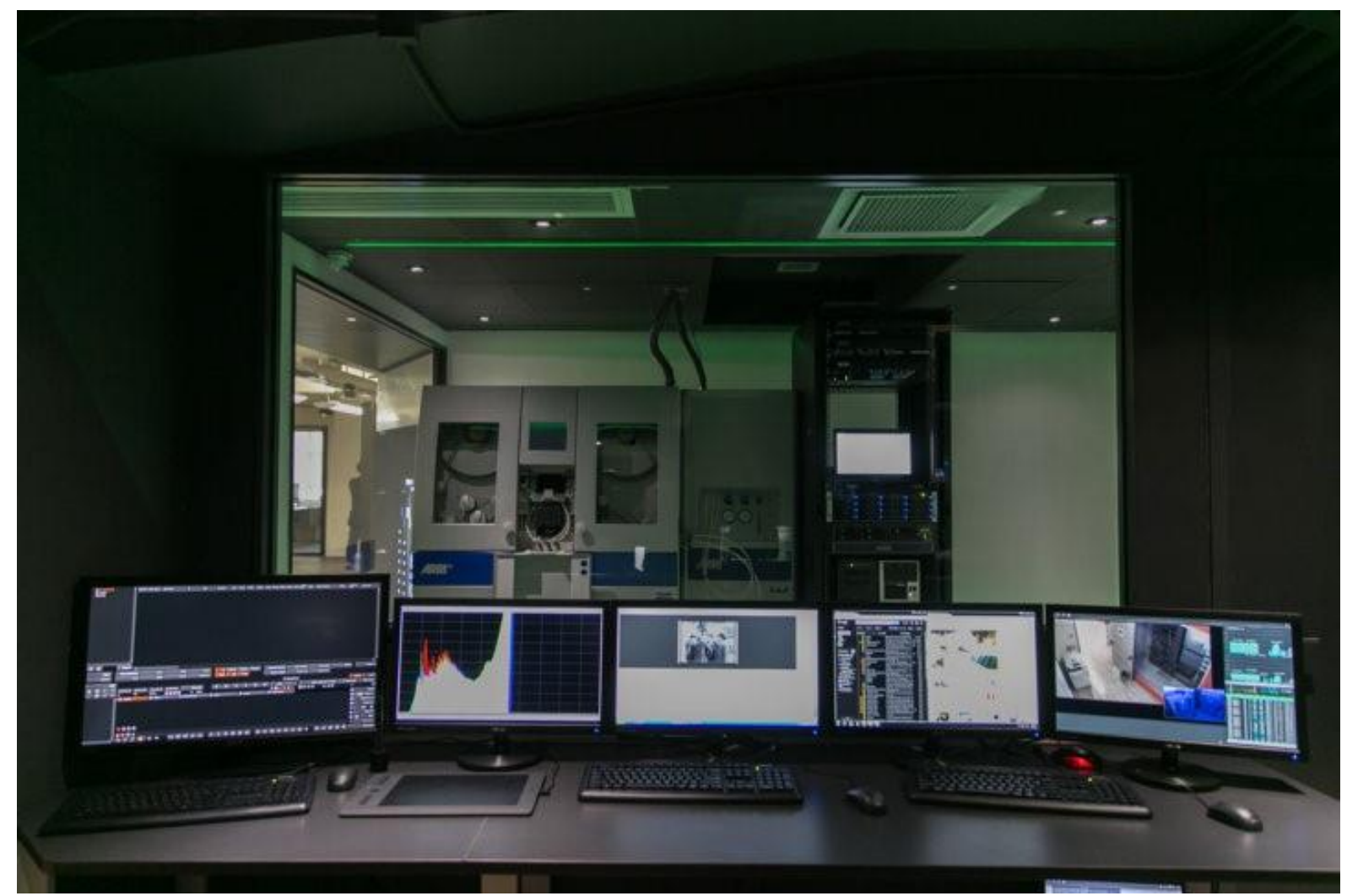

Figure 8: L'Immagine Ritrovata Asia: quality control workstation

AG: Film festivals have increasingly become key nodes in the circulation of newly restored films. How do you see the trend influencing the field of film preservation and restoration? Do film festivals ever commission restoration projects?

BC: Every year we have films in Cannes Classics, Venice, the Berlinale, and most of the latest restorations from L'Immagine Ritrovata are premiered at festivals. Essentially, film festivals have always been launching pads for new films, but now they are launching pads also for new "old" films. For instance, the restored version of King Hu's A Touch of Zen (Taiwan, 1975) was launched at the Cannes Classics section. Also, in the same year, Hou Hsiao-Hsien won the prize as Best Director for The Assassin (Taiwan, 2015), and so, it was a big year for Taiwan. This goes back to the point that a restored film is a kind of national pride. Of course, for Taiwan this is very important because their film market has always been marginalised by China within the international arena, and so, they have to do something to make themselves visible and also distinguish themselves from Chinese cinema.

Film is a very good medium to show one nation's heritage to the rest of the world. In a way, this is an incentive for a nation to have films restored. And yes, film festivals do commission film restoration. This happens quite often, actually. The Udine Far East Film Festival has done two projects with us: Johnnie To's Throw Down (Hong Kong, 2004) and Fruit Chan's Made in Hong Kong (Hong Kong, 1997). The Shanghai Film Festival also commissioned us for the restoration of a few titles, including John Woo's A Better Tomorrow (Hong Kong, 1986).

AG: The shift to digital distribution has changed the market for audiovisual products tout court, but how do you see it impacting and shaping the economy of film restoration? Has 
the digital turn effectively opened new ways to make cinema's history accessible to wider audiences?

BC: The digital platforms need to have content and widen their catalogues, not just with brand new films. They give old films, classic films, restored films a new channel to be distributed through. They have created a new market to cater for, and if there is a new market for old cinema then there is also a way to make more money out of it. This is another big incentive to restore films. This leads us to consider a problem that may come in the near future: bad practices in film restoration. Restoration is something that takes a long time, involves lots of effort, and is quite expensive. However, the increasing competition in the field of film restoration together with the growing demand for classic films is pushing companies to hasten the restoration process that tends to prioritise its outcome rather than its quality. People will just see the label "restored" on a film but won't go through all the details of how bad or good that restoration actually is. All that people care about is looking at some shining image. They do not care about the frame rate or aspect ratio. Nowadays, audiences are used to films shot digitally, that are very comfortable to look at, and because of that, even filmmakers want their restored films to look equally clean and sharp.

I believe that, since there is not a standard for what a restored film should look like, this business risks following the false belief that a film should have a digital and comfortable look to satisfy audiences' desires. I think that today the terms "restored" and "restoration" are being abused. Therefore, educating cinemagoers and people who love cinema about what a film restoration is should be key aim for our institutions.

AG: Do you agree that restoring and preserving cinema's memory has become an effort that, these days, normally involves specialists and institutions from more than one country?

BC: This question leads me back to something I talked about at the beginning of this interview. A lot of Hong Kong films were distributed across the world and in Southeast Asia, so now if we want to reconstruct the history of this cinema we need to retrace the transnational circulation of these films and cooperate with institutions based in other countries. This is especially true for Hong Kong cinema from the 1980s and 1990s. We have restored films that were co-produced in the 1960s by South Korean and Hong Kong companies. At that time, the Shaw Brothers were hiring South Korean directors to shoot films in Hong Kong. So, nowadays, since the Korean Film Archive (KOFA) is trying to get these films back, they asked us to scan copies and carried out the actual restoration by themselves.

\footnotetext{
${ }^{1}$ Notable exceptions are the Sinematek Indonesia and the Bangladesh Film Archive, which are the first film archival organisations to be established in South East Asia, respectively in 1975 and 1978.
}

\section{About the Interviewee}

Bede Cheng started his media career in radio production in Hong Kong, and later worked in a variety of posts on film and television productions: assistant director, line-producer, script supervisor, and camera crew. Since 2002, he became involved with programming at the Hong 
Kong Film Archive, later as Programme Manager of the Hong Kong International Film Festival Society, and Senior Programme Manager of The Metroplex Cinema. He facilitated bringing in the inaugural edition of Sundance Festival to Hong Kong. He is currently the Managing Director of L'lmmagine Ritrovata Asia, the Hong Kong-based branch of the film Italian restoration laboratory.

\begin{abstract}
About the Interviewer
Andrea Gelardi is a PhD Candidate at the Department of Film Studies of the University of St Andrews. Funded by the AD Links Foundation and the Russell Trust, his research focuses on the history, politics and economy of the Cineteca di Bologna, tracing the relationship between film institutions' practices and world cinema historiographic developments. His work has been published in Excursions, Alphaville and Imago and he collaborates with specialised journals like Cinergie, Frames Cinema Journal and Studies in European Cinema.
\end{abstract}

